\title{
Effects of Temperature and Grafting on Yield, Nutrient Uptake, and Water Use Efficiency of a Hydroponic Sweet Pepper Crop
}

\author{
Andreas Ropokis ${ }^{1}$, Georgia Ntatsi ${ }^{1,2}(0)$, Constantinos Kittas ${ }^{3}$, Nikolaos Katsoulas ${ }^{3, *}$ \\ and Dimitrios Savvas $1, *$ (D) \\ 1 Department of Crop Science, Laboratory of Vegetable Crops, Agricultural University of Athens, Iera Odos, \\ 75, 11855 Athens, Greece; ropokis@aua.gr (A.R.); ntatsi@aua.gr (G.N.) \\ 2 Institute of Plant Breeding and Genetic Resources ELGO-DEMETER, Thermi, 57001 Thessaloniki, Greece \\ 3 Department of Agriculture Crop Production and Rural Environment, University of Thessaly, 38446 Volos, Greece; \\ ckittas@uth.gr \\ * Correspondence: nkatsoul@uth.gr (N.K.); dsavvas@aua.gr (D.S.); Tel.: +30-2421-093-249 (N.K.); \\ $+30-210-529-4510$ (D.S.)
}

Received: 11 January 2019; Accepted: 22 February 2019; Published: 25 February 2019

check for updates

\begin{abstract}
In areas characterized by mild winter climate, pepper is frequently cultivated in unheated greenhouses in which the temperature during the winter may drop to suboptimal levels. Under low temperature (LT) conditions, the uptake of nutrients may be altered in a different manner than that of the water and thus their uptake ratio, known as uptake concentration, may be different than in greenhouses with standard temperature (ST) conditions. In the present study, pepper plants of the cultivars "Sammy" and "Orangery", self-grafted or grafted onto two commercial rootstocks ("Robusto" and "Terrano"), were cultivated in a greenhouse under either ST or LT temperature conditions. The aim of the study was to test the impact of grafting and greenhouse temperature on total yield, water use efficiency, and nutrient uptake. The LT regime reduced the yield by about 50\% in "Sammy" and 33\% in "Orangery", irrespective of the grafting combination. Grafting of "Sammy" onto both "Robusto" and "Terrano" increased the total fruit yield by $39 \%$ and $34 \%$ compared with the self-grafted control, while grafting of "Orangery" increased the yield only when the rootstock was "Terrano". The yield increase resulted exclusively from enhancement of the fruit number per plant. Both the water consumption and the water use efficiency were negatively affected by the LT regime, however the temperature effect interacted with the rootstock/scion combination. The LT increased the uptake concentrations (UC) of $\mathrm{K}, \mathrm{Ca}, \mathrm{Mg}, \mathrm{N}$, and $\mathrm{Mn}$, while it decreased strongly that of $\mathrm{P}$ and slightly the UC of Fe and $\mathrm{Zn}$. The UC of $\mathrm{K}$ and $\mathrm{Mg}$ were influenced by the rootstock/scion combination, however this effect interacted with the temperature regime. In contrast, the $\mathrm{Ca}, \mathrm{N}$, and $\mathrm{P}$ concentrations were not influenced by the grafting combination. The results of the present study show that the impact of grafting on yield and nutrient uptake in pepper depend not merely on the rootstock genotype, however on the rootstock/scion combination.
\end{abstract}

Keywords: abiotic stress; Capsicum annuum L.; calcium; rootstock; uptake concentrations; soilless culture

\section{Introduction}

The concentration of each nutrient in nutrient solutions supplied to plants in closed hydroponic systems should be equal to the corresponding nutrient to water uptake ratio to avoid depletion or accumulation in the root zone [1]. The unit used to measure nutrient to water uptake ratios is mass of nutrient per water volume, which is identical to that used for concentrations in nutrient 
solutions. Therefore, several authors use the term "uptake concentration" (UC) to describe the nutrient to water uptake ratios [2-7]. Nutrient uptake and water uptake respond differently to changes in the greenhouse microclimate, since physiologically these are two fully independent processes [8]. However, $\mathrm{CO}_{2}$ and water vapor share the same transport pathways as they pass through leaf stomata, through to different directions. As a result, the fluctuations in the transpiration to assimilation ratio, as expressed in terms of water use efficiency, are small for a particular plant species [9]. Since the rates of carbon fixation determine also the plant dry mass accumulation and concomitantly the plant nutrient requirements [10], the nutrient-to-water uptake ratio exhibits a noticeable stability with time, as has been shown by several investigators $[6,11,12]$. This is particularly true if the climatic conditions do not change dramatically compared to optimal levels [1,3]. Nevertheless, major changes in climatic parameters may differently influence the uptake rates of one or more nutrients compared to those of water uptake, thereby imposing commensurate changes in their uptake ratio [13]. This is particularly true if a climatic parameter strongly deviates from the optimal range, thereby imposing stress conditions that alter differently the uptake of a nutrient than that of water at a physiological level other than transpiration.

The minimum temperature threshold for growth of most of the chilling-sensitive fruit vegetables, such as pepper (Capsicum annuum L.), eggplant (Solanum melongena L.), cucumber (Cucumis sativus L.), tomato (S. lycopersicum L.), and melon (C. melo, L.), is about $8-12{ }^{\circ} \mathrm{C}[14,15]$. In most Mediterranean greenhouses used for the production of fruit and vegetables, heating during the cold season of the year is either not applied or applied sporadically, aiming merely to maintain the inside temperature to levels higher than the minimum threshold for growth $[16,17]$. However, under low temperature conditions, plant metabolism, and concomitantly nutrient requirements, may change substantially compared to optimal temperature conditions. Furthermore, the transpiration rates, and concomitantly the water uptake, alter considerably under low temperature conditions $[18,19]$. Hence, the nutrient to water uptake ratios may change considerably compared to those determined under optimal temperature conditions if the mean temperature inside a greenhouse is substantially lower than the standard range.

Grafting has been used as an efficient crop protection technology in fruit and vegetable production for more than 50 years in many parts of the world [20]. Grafting is not associated with agrochemical input to the crops and, therefore, it is considered an environmentally-friendly operation in integrated vegetable production [21,22]. Furthermore, grafting proved to be an efficient technology to increase the tolerance of fruit and vegetables to several abiotic stress factors such as salinity, nutrient deficiencies or toxicities, exposure to heavy metals, etc. [23]. Therefore, grafting serves in many cases as a rapid alternative to breeding, which is considered a relatively slow methodology of conferring tolerance to biotic and abiotic stress, while its effectiveness is frequently restricted due to a narrow genetic variability $[24,25]$.

The application of grafting is less widespread in the commercial production of sweet pepper compared to tomato, cucumber, and watermelon [26]. Nevertheless, in recent years, several rootstocks used to graft sweet pepper proved to confer considerable tolerance to biotic and abiotic stress factors [27-29]. Therefore, the interest in pepper grafting has increased appreciably among greenhouse pepper producers in recent years. However, compared to tomato, very little is known about the impact of grafting on nutrient uptake by pepper [30]. Furthermore, to the best of our best knowledge, no report has been published to date in peer-reviewed journals addressing the impact of suboptimal or low temperature on nutrient uptake by grafted pepper plants. The impact of grafting and suboptimal temperature on nutrient uptake concentrations is very crucial also for the application of closed soilless systems in pepper cultivation in most Mediterranean greenhouses. In view of this background, the present paper was designed to test whether grafting alters the nutrient to water uptake ratios (i.e., uptake concentrations) in pepper crops grown in unheated or inadequately heated greenhouses under Mediterranean climatic conditions. 


\section{Materials and Methods}

\subsection{Plant Material and Growth Conditions}

The experiment was carried out in two different compartments of a heated glasshouse at the Agricultural University of Athens $\left(37^{\circ} 58^{\prime} 57.8^{\prime \prime} \mathrm{N}, 23^{\circ} 42^{\prime} 14.3^{\prime \prime}\right.$ E). During the whole experimental period, the minimum day/night temperature was maintained constantly at 21/16 ${ }^{\circ} \mathrm{C}$ and $12 / 7^{\circ} \mathrm{C}$ in compartments 1 and 2, respectively, corresponding to a standard temperature (ST) and a low temperature (LT) treatment, respectively. In both compartments, two sweet pepper cultivars (Capsicum annuum L.) either self-grafted or grafted onto two different rootstocks were grown in recirculating nutrient solution (NS) according to the principles of the Nutrient Film Technique (NFT). The two bell pepper cultivars were one blocky type ("Orangery") and one elongated type ("Sammy"), while the two rootstocks were "Robusto" and "Terrano", both belonging to Capsicum annuum. The obtained grafting combinations were "Sammy" /"Sammy", "Robusto" / "Sammy", "Terrano" /"Sammy", "Orangery" / "Orangery", "Robusto" / Orangery", and "Terrano"/ "Orangery". Each treatment was replicated three times and thus 36 experimental hydroponic circuits (EHC) were used. Each EHC comprised one channel, $3.0 \mathrm{~m}$ in length, $0.15 \mathrm{~m}$ in width, and $0.30 \mathrm{~m}$ in height, and consisted of an individual supply tank, a pump, and irrigation pipes.

Splice grafting was performed when seedlings had developed 3-4 true leaves. The rootstock seeds were sown three days before those of the scion to compensate for the slower growth rate of the former in the hetero-grafting treatments. On 29 November, when the grafted seedlings had developed 5-6 true leaves, they were transferred into the 36 EHC. Each EHC accommodated nine plants and this arrangement resulted in a plant density of 2.5 plants per $\mathrm{m}^{2}$. Climatic data during the experiment are shown in Figure 1.

In each channel, the NS was automatically pumped at a rate of $0.4 \mathrm{~m}^{3} \mathrm{~h}^{-1}$, while the total volume of NS recirculating in the closed circuit amounted to $3 \mathrm{~L} \mathrm{~s}^{-1}$ plant $^{-1}$. The level of NS in the supply tank was maintained at a constant using a floater and a pipe connected to a "replenishment tank", which was positioned above it. Thus, the NS consumed by the plants was compensated by automatic injection of a NS with a composition suitable for pepper cultivation in closed hydroponic systems, henceforth termed Nutrient Solution for Closed Systems (NSCS) [31], which was contained in the replenishment tank. The recirculating nutrient solution was not discharged and not replaced by fresh solution during the period of measuring the UC. The composition of the NSCS was assumed to be roughly equal to standard uptake concentrations for pepper, as estimated in a previous paper [30]. The NS consumed by the plants was counted daily by recording the level difference in the replenishment tank and, thus, the cumulative water consumption could be precisely estimated. Once per day, the $\mathrm{pH}$ in the recirculating NS was adjusted to 5.6 by adding appropriate amounts of nitric acid $(1 \mathrm{~N})$ or potassium hydroxide $(1 \mathrm{~N})$ to the supply tank, based on the actual $\mathrm{pH}$ level that was measured using a portable $\mathrm{pH}$-meter. All channels were covered with black-white polyethylene sheets to avoid water evaporation. No drainage water was discharged and losses due to technical failures were negligible.

Before transplanting, all supply tanks were filled with a starter NS, while all replenishment tanks were filled with NSCS. Immediately after transplanting, NSCS was supplied to the plants through the floater in all circuits to compensate for nutrient solution uptake by the plants. 


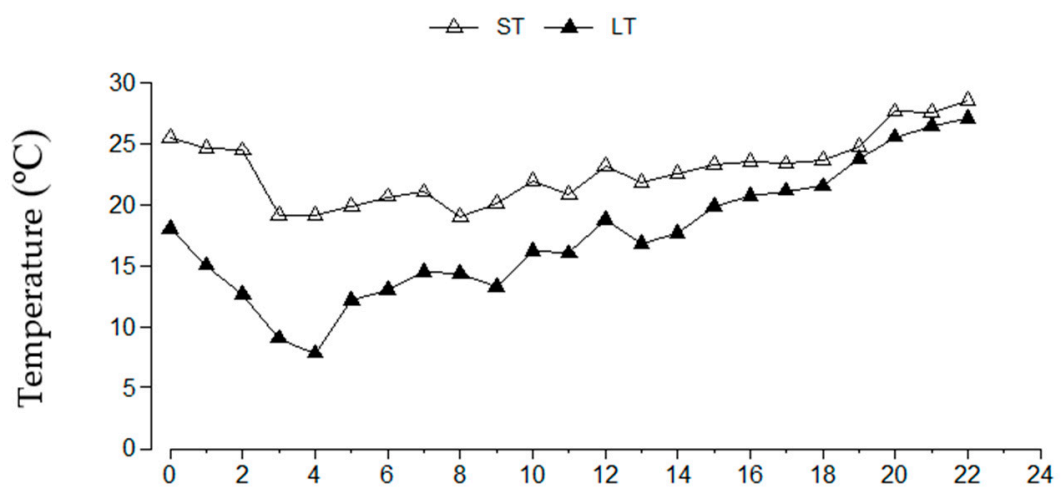

Weeks from treatment initiation

(a)

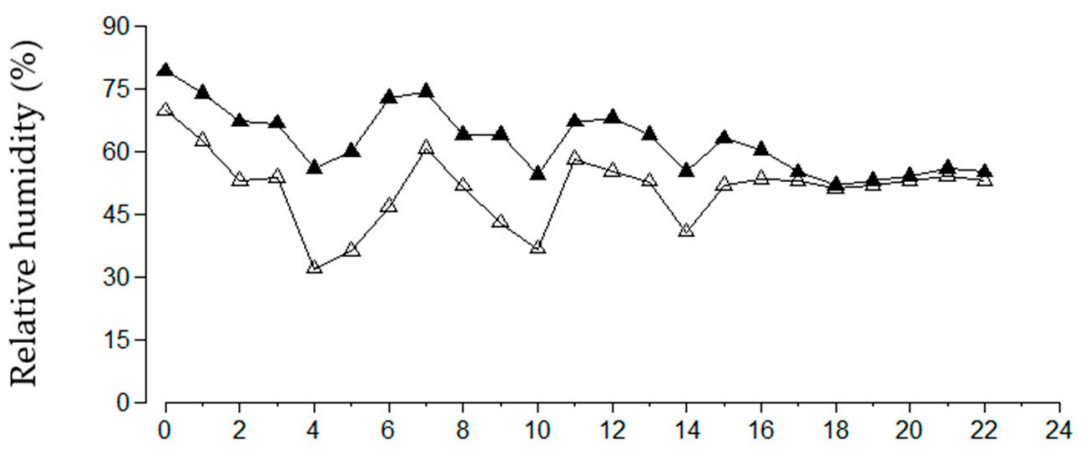

Weeks from treatment initiation

(b)

Figure 1. Fluctuations of (a) mean temperature $\left({ }^{\circ} \mathrm{C}\right)$ and $(\mathbf{b})$ mean relative humidity $(\%)$ during 790 degree-days from treatment initiation in two greenhouse compartments in which a standard temperature (ST) and a low temperature (LT) regime were maintained during the experimental period (from 29 November to 20 May).

\subsection{Leaf Biomass, Yield, Water Consumption, and Water Use Efficiency}

On 6 February, two plants were collected from each experimental unit and the leaf fresh weigh was measured (LFW). Harvesting commenced on 6 February and on 23 March in the ST and LT compartments, respectively, and terminated on 20 May in both compartments. Commercially mature fruits were harvested twice per week to estimate the total fruit yield, the total number of fruit per plant, and the mean fruit weight in each treatment. Fruits from "Sammy" plants were physiologically unripe at commercial maturity, as this cultivar is harvested at the green-yellow maturity stage, while fruits from "Orangery" were harvested physiologically ripe, as they are commonly harvested when their color has fully turned to orange. Crop water use efficiency was calculated as fruit yield ( $\mathrm{kg} / \mathrm{plant})$ divided by the cumulative water consumption (L/plant).

\subsection{Composition and Sampling of Experimental Nutrient Solutions}

The nutrient concentrations in the starter NS were in all treatments as follows: $6.0 \mathrm{mM} \mathrm{K}^{+}, 6.5 \mathrm{mM}$ $\mathrm{Ca}^{2+}, 2.0 \mathrm{mM} \mathrm{Mg}^{2+}, 0.5 \mathrm{mM} \mathrm{NH}_{4}{ }^{+}, 15.6 \mathrm{mM} \mathrm{NO}_{3}{ }^{-}, 1.2 \mathrm{mM} \mathrm{H}_{2} \mathrm{PO}_{4}{ }^{-}, 3.1 \mathrm{mM} \mathrm{SO}_{4}{ }^{2-}, 15.0 \mu \mathrm{M} \mathrm{Fe}$, $10.0 \mu \mathrm{M} \mathrm{Mn}, 7.0 \mu \mathrm{M} \mathrm{Zn}, 0.7 \mu \mathrm{M} \mathrm{Cu}, 60.0 \mu \mathrm{M} \mathrm{B}$, and $0.5 \mu \mathrm{M}$ Mo. The EC and pH of the starter NS were $2.6 \mathrm{dS} \mathrm{m}^{-1}$ and 5.6, respectively. The nutrient concentrations in the NSCS were as follows: $7.0 \mathrm{mM}$ $\mathrm{K}^{+}, 3.0 \mathrm{mM} \mathrm{Ca}^{2+}, 1.25 \mathrm{mM} \mathrm{Mg}^{2+}, 1.0 \mathrm{mM} \mathrm{NH}_{4}{ }^{+}, 12.3 \mathrm{mM} \mathrm{NO}_{3}{ }^{-}, 1.1 \mathrm{mM} \mathrm{H}_{2} \mathrm{PO}_{4}{ }^{-}, 1.3 \mathrm{mM} \mathrm{SO}_{4}{ }^{2-}$, $15 \mu \mathrm{M}$ Fe, $10.0 \mu \mathrm{M} \mathrm{Mn}, 4.0 \mu \mathrm{M} \mathrm{Zn}, 0.7 \mu \mathrm{M} \mathrm{Cu}, 25.0 \mu \mathrm{M}$ B, and $0.5 \mu \mathrm{M}$ Mo. 
Immediately after transplanting, i.e., on 29 November, samples of starter and replenishment NS were collected from all EHC. After completion of 790 degree-days in both compartments, samples of recirculating NS were collected from all EHC. The collection of NS samples after 790 degree-days coincided with anthesis at the fourth internode in both compartments. However, due to the different temperature regimes in each compartment, the time needed to reach the same degree-days was different. Thus, the samples of recirculating NS were collected on 10 January in the ST compartment and on 7 February in the LT compartment. Collecting NS samples after completion of the same degree-days rather than the same time interval was aimed at comparing mean uptake concentrations for the same developmental stage, given that plant development is mainly determined by degree-days rather than by time per se.

\subsection{Determination of Nutrient Concentrations}

The concentrations of $\mathrm{Ca}, \mathrm{Mg}, \mathrm{Fe}, \mathrm{Mn}$, and $\mathrm{Zn}$ in the nutrient solution samples were measured using an atomic absorption spectrophotometer (Perkin Elmer 1100A, Perkin Elmer, Waltham, MA, USA), while that of $\mathrm{K}$ was determined by flame photometry (Sherwood Model 410, Cambridge, UK). The concentrations of $\mathrm{NO}_{3}-\mathrm{N}, \mathrm{NH}_{4}-\mathrm{N}, \mathrm{P}$, and $\mathrm{B}$ were measured photometrically using a 96-position microplate spectrophotometer (Anthos Zenyth 200; Biochrom, MA, USA). Nitrate N and ammonium $\mathrm{N}$ were determined by applying the copperized cadmium reduction method (Griess-Ilosvay procedure) at $540 \mathrm{~nm}$ and the indophenol blue method at $630 \mathrm{~nm}$, respectively. Phosphorus was measured as phosphomolybdate blue complex at $880 \mathrm{~nm}$. Boron was estimated photometrically at $420 \mathrm{~nm}$ by the azomethine- $\mathrm{H}$ method. The $\mathrm{NH}_{4}-\mathrm{N}$ concentration was added to that of $\mathrm{NO}_{3}-\mathrm{N}$ in each sample to obtain the total $\mathrm{N}$ concentration [30].

\subsection{Estimation of Mean Uptake Concentrations}

Mean nutrient to water uptake ratios (uptake concentrations) for $\mathrm{Ca}, \mathrm{Mg}$, $\mathrm{K}$, total-N, $\mathrm{P}, \mathrm{Fe}, \mathrm{Mn}$, $\mathrm{Zn}, \mathrm{Cu}$, and $\mathrm{B}$ were estimated by measuring the total removal of each nutrient from the recirculating nutrient solution and the water uptake during a cropping period corresponding to 790 degree-days in both compartments. More specifically, the mean uptake concentration of the $i$ nutrient $\left(C_{i u}\right.$ in mmol $\mathrm{L}^{-1}$ for macronutrients and $\mu \mathrm{mol} \mathrm{L}{ }^{-1}$ for micronutrients, where $i=\mathrm{Ca}, \mathrm{Mg}, \mathrm{K}, \mathrm{P}$, total- $\mathrm{N}, \mathrm{Fe}, \mathrm{Mn}, \mathrm{Zn}$, and $\mathrm{B})$ was determined using the following mass balance equation [32]:

$$
C_{i u}=\left(V_{r}\left(C_{i b}-C_{i e}\right)+V_{u} C_{i c}\right) / V_{u}
$$

where $V_{r}$ (L) denotes the total volume of recirculating nutrient solution in each experimental unit, $V_{u}(\mathrm{~L})$ denotes the total volume of NS that was taken up by the plants in each experimental unit during the experimental period, $C_{i b}$ and $C_{i e}\left(\mathrm{mmol} \mathrm{L}^{-1}\right.$ for macronutrients and $\mu \mathrm{mol} \mathrm{L}^{-1}$ for micronutrients) denote the concentrations of the $i$ nutrient in the recirculating NS on the first and the last day of the experimental period, and $\mathrm{C}_{\mathrm{ic}}\left(\mathrm{mmol} \mathrm{L}{ }^{-1}\right.$ for macronutrients and $\mu \mathrm{mol} \mathrm{L} \mathrm{L}^{-1}$ for micronutrients) denotes the concentration of the $i$ nutrient in the NSCS.

\subsection{Statistical Analysis}

Yield and yield components were evaluated separately for each cultivar ("Sammy" and "Orangery") to more clearly demonstrate the impact of the rootstock on pepper fruit production as statistically comparing yield performance of two different types of pepper makes no sense. Thus, for each cultivar, a 2-factorial split-plot experimental design was applied (temperature $\times$ rootstock) with two temperature regimes (normal and low) and three grafting treatments (self-grafting, grafting onto "Terrano", and grafting onto "Robusto"). However, for water consumption, water use efficiency, and nutrient/water uptake, it was interesting to statistically test if they were differently affected by each cultivar. Therefore, for these parameters, two temperature regimes (ST and LT) and six scion/rootstock combinations were evaluated in a single 2-factorial 
split-plot experimental design. The impact of the different treatments was evaluated by applying 2-factorial ANOVA, while multiple comparisons of means were performed by applying the Duncan's Multiple Range Test. The STATISTICA software package, version 12.0 (StatSoft, Inc., Tulsa, OK, USA) was used to statistically evaluate the data.

\section{Results}

The LT regime reduced the total fruit yield by about 50\% in "Sammy" and 33\% in "Orangery", and the fresh leaf biomass by about 72\% in "Sammy" and 50\% in "Orangery", irrespective of the grafting combination (Table 1). Grafting onto both "Robusto" and "Terrano" raised the total fruit yield of "Sammy" by about 35\% in comparison to self-grafting. However, when the scion was "Orangery", only grafting onto "Terrano" was capable of increasing the total fruit yield and the fresh leaf biomass compared to self-grafting, whereas grafting onto "Robusto" had no significant impact on yield and fresh leaf biomass. The yield increase in "Sammy" due to grafting onto both "Robusto" and "Terrano" resulted exclusively from an increase in the fruit number per plant, while the mean fruit weight and the fresh leaf biomass were not influenced by grafting. The yield increase imposed by grafting of "Orangery" onto "Terrano" was also a result of a commensurate increase in the fruit number per plant. Finally, grafting of "Orangery" onto "Robusto" proved to provide no yield benefits, not only because it failed to increase the fruit number per plant, however also because it significantly reduced the mean fruit weight.

Table 1. Impact of temperature $(\mathrm{T})$ and grafting of two cultivated pepper varieties, i.e., "Sammy" (S), and "Orangery" $(\mathrm{O})$, self-grafted or grafted onto the rootstocks "Robusto" or "Terrano", and grown in recirculating nutrient solution on total fruit weight (TFW), total fruit number (TFN), mean fruit weight (MFW) per plant, and fresh leaf weight (FLW).

\begin{tabular}{|c|c|c|c|c|c|c|c|c|}
\hline \multirow{2}{*}{$\begin{array}{c}\begin{array}{c}\text { Temperature } \\
\left({ }^{\circ} \mathrm{C}\right)\end{array} \\
\text { Rootstock }\end{array}$} & \multicolumn{2}{|c|}{ TFW (Kg plant $\left.{ }^{-1}\right)$} & \multicolumn{2}{|c|}{ TFN (No plant ${ }^{-1}$ ) } & \multicolumn{2}{|c|}{ MFW (g fruit ${ }^{-1}$ ) } & \multicolumn{2}{|c|}{ FLW (g plant ${ }^{-1}$ ) } \\
\hline & $S$ & $\mathrm{O}$ & $S$ & $\mathrm{O}$ & $S$ & $\mathrm{O}$ & $S$ & $\mathrm{O}$ \\
\hline \multicolumn{9}{|c|}{ Main effects } \\
\hline Standard T & $3.10 \mathrm{a}$ & $2.14 \mathrm{a}$ & $57.10 \mathrm{a}$ & 18.75 & $54.29 \mathrm{a}$ & $114.13 \mathrm{a}$ & $161 \mathrm{a}$ & $129 \mathrm{a}$ \\
\hline Low $\mathrm{T}$ & $1.50 \mathrm{~b}$ & $1.43 \mathrm{~b}$ & $42.35 \mathrm{~b}$ & 20.73 & $35.42 \mathrm{~b}$ & $68.98 \mathrm{~b}$ & $45 \mathrm{~b}$ & $64 b$ \\
\hline Self-grafted & $1.85 \mathrm{~b}$ & $1.57 \mathrm{~b}$ & $42.20 \mathrm{~b}$ & $16.00 \mathrm{~b}$ & 43.84 & $98.13 \mathrm{a}$ & 107 & $87 \mathrm{~b}$ \\
\hline "Robusto" & $2.57 \mathrm{a}$ & $1.64 \mathrm{~b}$ & $53.28 \mathrm{a}$ & $20.51 \mathrm{ab}$ & 48.24 & $79.96 \mathrm{~b}$ & 96 & $83 \mathrm{~b}$ \\
\hline “Terrano” & $2.49 \mathrm{a}$ & $2.14 \mathrm{a}$ & $53.70 \mathrm{a}$ & $22.71 \mathrm{a}$ & 46.37 & $94.23 \mathrm{a}$ & 105 & $115 \mathrm{a}$ \\
\hline \multicolumn{9}{|c|}{ Statistical significance } \\
\hline $\begin{array}{l}\text { Temperature } \\
\text { (T) }\end{array}$ & $* * *$ & $* *$ & $* *$ & ns & $* * *$ & $* * *$ & $* * *$ & $* *$ \\
\hline Rootstock (R) & $* * *$ & $*$ & $* *$ & $*$ & ns & $*$ & ns & $*$ \\
\hline $\mathrm{T} \times \mathrm{R}$ & ns & ns & ns & ns & ns & ns & ns & ns \\
\hline
\end{tabular}

As shown in Table 2, the low temperature significantly decreased the water consumption of "Sammy" plants irrespective of the grafting combination, while it had no significant impact on the water consumption of "Orangery" plants. Grafting onto the rootstock "Robusto" had no impact on plant water consumption, while grafting onto "Terrano" increased the water consumption only when the scion was "Orangery". The water use efficiency (WUE) decreased considerably at low temperature, irrespective of the rootstock/scion combination. Hetero-grafting of "Sammy" significantly increased the WUE irrespective of the scion at LT, however only when the rootstock was "Robusto" at ST. However, grafting of "Orangery" had no impact on WUE, irrespective of the rootstock and the temperature regime. 
Table 2. Impact of temperature $(\mathrm{T})$ and grafting of two cultivated pepper varieties, i.e., "Sammy" $(\mathrm{S})$ and "Orangery" $(\mathrm{O})$, self-grafted or grafted onto the rootstocks "Robusto" or "Terrano", and grown in recirculating nutrient solution on cumulative water consumption (CWC) and water use efficiency (WUE).

\begin{tabular}{|c|c|c|c|}
\hline Temperature $\left({ }^{\circ} \mathrm{C}\right)$ & $\begin{array}{l}\text { Grafting Combination } \\
\text { (Rootstock/Scion) }\end{array}$ & CWC (L plant $\left.{ }^{-1}\right)$ & WUE $\left(\mathrm{g} \mathrm{L}^{-1}\right)$ \\
\hline \multicolumn{4}{|c|}{ Main effects } \\
\hline \multirow{8}{*}{$\begin{array}{l}\text { Standard T } \\
\text { Low T }\end{array}$} & & 48.48 & 54.05 \\
\hline & & 36.84 & 39.77 \\
\hline & ny"/“Sammy" & 48.13 & 37.18 \\
\hline & sto" / "Sammy" & 47.94 & 51.89 \\
\hline & no"/"Sammy" & 49.99 & 48.18 \\
\hline & gery"/“Orangery" & 32.49 & 47.65 \\
\hline & sto" / "Orangery" & 35.72 & 45.70 \\
\hline & no"/“Orangery" & 41.70 & 50.85 \\
\hline \multicolumn{4}{|c|}{ Interactions } \\
\hline \multirow{6}{*}{ Standard } & "Sammy" /"Sammy" & $55.00 \mathrm{a}$ & $45.95 \mathrm{bc}$ \\
\hline & "Robusto" / "Sammy" & $56.31 \mathrm{a}$ & $61.62 \mathrm{a}$ \\
\hline & "Terrano" /"Sammy" & $62.72 \mathrm{a}$ & $52.54 \mathrm{~b}$ \\
\hline & “Orangery" / “Orangery” & $35.24 \mathrm{~cd}$ & $55.71 \mathrm{a}$ \\
\hline & "Robusto" /“Orangery" & $36.89 \mathrm{~cd}$ & $50.74 \mathrm{ab}$ \\
\hline & “Terrano" / "Orangery” & $44.70 \mathrm{~b}$ & $57.71 \mathrm{a}$ \\
\hline \multirow{6}{*}{ Low } & "Sammy"/"Sammy" & $41.25 \mathrm{bc}$ & $28.41 \mathrm{~d}$ \\
\hline & "Robusto" /"Sammy" & $39.57 \mathrm{bc}$ & $42.15 c$ \\
\hline & “Terrano”/“ Sammy” & $37.26 \mathrm{bcd}$ & $43.82 \mathrm{c}$ \\
\hline & "Orangery" / "Orangery" & $29.73 \mathrm{~d}$ & $39.59 c$ \\
\hline & "Robusto" / "Orangery" & $34.54 \mathrm{~cd}$ & $40.66 \mathrm{c}$ \\
\hline & "Terrano" / "Orangery" & $38.70 \mathrm{bc}$ & $43.99 \mathrm{bc}$ \\
\hline \multicolumn{4}{|c|}{ Statistical significance } \\
\hline & $* * *$ & $* * *$ \\
\hline \multicolumn{2}{|c|}{ Grafting combination } & $* * *$ & $* *$ \\
\hline \multicolumn{2}{|c|}{ Temperature $\times$ grafting combination } & $* *$ & $* *$ \\
\hline
\end{tabular}

The uptake concentration (UC) of K was significantly higher under LT than under ST conditions in self-grafted plants as well as in plants grafted onto "Robusto", irrespective of the scion (Table 3). However, this difference was not significant in plants of both "Sammy" and "Orangery" when they were grafted onto "Terrano" because "Terrano" significantly increased the UC of K by both "Orangery" and "Sammy" under ST conditions compared to the other grafting combinations. The UCs of calcium were not influenced by any grafting combination, however were significantly higher at the LT regime in the greenhouse. Similarly to K, the UC of magnesium was significantly higher under LT than under ST conditions in self-grafted plants as well as in plants grafted onto "Robusto", irrespective of the scion, while they were not influenced by LT when both cultivars were grafted onto "Terrano". Grafting onto both "Robusto" and "Terrano" enhanced the Mg UC in the HT regime, while under LT conditions, only Robusto was capable of increasing the Mg UC. 
Table 3. Mean uptake concentrations (UC) of potassium (K), calcium (Ca), and magnesium (Mg) in a pepper crop grown in recirculating nutrient solution during 790 degree-days from treatment initiation, as influenced by temperature (T) and grafting of two cultivated varieties, i.e., "Orangery" and "Sammy", either on their roots or onto the rootstocks "Robusto" and "Terrano".

\begin{tabular}{|c|c|c|c|c|}
\hline Temperature $\left({ }^{\circ} \mathrm{C}\right)$ & $\begin{array}{l}\text { Grafting Combination } \\
\text { (Rootstock/Scion) }\end{array}$ & $\mathrm{K} \mathrm{UC}\left(\mathrm{mmol} \mathrm{L}^{-1}\right)$ & Ca UC $\left(\mathrm{mmol} \mathrm{L}^{-1}\right)$ & $\operatorname{Mg~UC~}\left(\mathrm{mmol} \mathrm{L}^{-1}\right)$ \\
\hline \multicolumn{5}{|c|}{ Main effects } \\
\hline Standard T & & 6.03 & $2.92 \mathrm{~b}$ & 0.92 \\
\hline \multirow[t]{7}{*}{ Low $\mathrm{T}$} & & 6.85 & $3.57 \mathrm{a}$ & 1.19 \\
\hline & "Sammy" /"Sammy" & 6.33 & 3.18 & 0.95 \\
\hline & "Robusto" / "Sammy" & 6.49 & 3.36 & 1.25 \\
\hline & "Terrano" / "Sammy" & 6.78 & 3.32 & 1.09 \\
\hline & "Orangery" / "Orangery" & 5.97 & 3.03 & 0.89 \\
\hline & "Robusto" / "Orangery" & 6.23 & 3.27 & 1.13 \\
\hline & "Terrano" / "Orangery" & 6.86 & 3.31 & 1.04 \\
\hline \multicolumn{5}{|c|}{ Interactions } \\
\hline \multirow{6}{*}{ Standard } & "Sammy" /"Sammy" & $5.62 \mathrm{~cd}$ & 3.02 & $0.73 \mathrm{~d}$ \\
\hline & "Robusto" / "Sammy" & $5.94 \mathrm{bc}$ & 3.08 & $1.10 \mathrm{bc}$ \\
\hline & "Terrano" / "Sammy" & $6.90 \mathrm{a}$ & 2.97 & $1.05 \mathrm{bc}$ \\
\hline & "Orangery" /"Orangery" & $5.12 \mathrm{~d}$ & 2.51 & $0.67 \mathrm{~d}$ \\
\hline & "Robusto" / "Orangery" & $5.77 \mathrm{~cd}$ & 3.01 & $0.94 \mathrm{c}$ \\
\hline & "Terrano" / "Orangery" & $6.84 \mathrm{ab}$ & 2.91 & $1.04 \mathrm{bc}$ \\
\hline \multirow{6}{*}{ Low } & "Sammy" /"Sammy" & $7.03 \mathrm{a}$ & 3.34 & $1.17 \mathrm{~b}$ \\
\hline & "Robusto" / "Sammy" & $7.04 \mathrm{a}$ & 3.64 & $1.40 \mathrm{a}$ \\
\hline & "Terrano" / "Sammy" & $6.65 \mathrm{ab}$ & 3.66 & $1.12 b c$ \\
\hline & "Orangery" / "Orangery" & $6.81 \mathrm{a}$ & 3.54 & $1.10 \mathrm{bc}$ \\
\hline & "Robusto" / "Orangery" & $6.69 \mathrm{ab}$ & 3.52 & $1.32 \mathrm{a}$ \\
\hline & "Terrano" / "Orangery" & $6.87 \mathrm{ab}$ & 3.70 & $1.03 \mathrm{bc}$ \\
\hline \multicolumn{5}{|c|}{ Statistical significance } \\
\hline \multirow{3}{*}{\multicolumn{2}{|c|}{$\begin{array}{l}\text { Temperature } \\
\text { Grafting combination } \\
\text { Temperature } \times \text { grafting }\end{array}$}} & $* * *$ & $* * *$ & $* * *$ \\
\hline & & * & ns & $* * *$ \\
\hline & & $* *$ & ns & $* *$ \\
\hline
\end{tabular}

$\mathrm{ns},{ }^{*}, * *$, and ${ }^{* * *}$ denote "not significant" or significance at $p \leq 0.05,0.01$, and 0.001 , respectively. Means $(n=3)$ followed by different letters within the same column indicate significant differences for each factor according to the Duncan's multiple range test.

The UCs of total $\mathrm{N}$ was significantly lower, while that of $\mathrm{P}$ was significantly higher under standard temperature conditions compared to low temperature, irrespective of cultivar and root genotype (Table 4). The rootstock/scion combination had no significant impact on the UC of total N and $\mathrm{P}$ and the interaction between temperature regime and grafting was insignificant.

Under ST conditions, the UCs of Fe and Zn were significantly higher, while that of Mn was significantly lower compared to LT without any significant interaction between temperature regime and rootstock/scion combination (Table 5). Furthermore, the grafting combination had no significant impact on the UCs of Fe and Zn. However, the UC of Mn was significantly influenced by both the cultivar and grafting. In particular, "Orangery" was taking up significantly more Mn per Liter of water absorbed than "Sammy", irrespective of the root genotype. Furthermore, hetero-grafting onto both "Robusto", and "Terrano" reduced the mass of Mn uptake per L of water absorbed by "Orangery", while it had no impact on the UC of Mn by "Sammy". The UC of B was not influenced by temperature regime or by the rootstock/scion combination. 
Table 4. Mean uptake concentrations (UC) of total nitrogen (total-N) and phosphorus (P) in a pepper crop grown in recirculating nutrient solution during 790 degree-days from treatment initiation, as influenced by temperature (T) and grafting of two cultivated varieties, i.e., "Orangery" and "Sammy", either on their roots or onto the rootstocks "Robusto" and "Terrano".

\begin{tabular}{|c|c|c|c|}
\hline Temperature $\left({ }^{\circ} \mathrm{C}\right)$ & $\begin{array}{l}\text { Grafting Combination } \\
\text { (Rootstock/Scion) }\end{array}$ & Total-N UC $\left(\mathrm{mmol} \mathrm{L}^{-1}\right)$ & P UC $\left(\mathrm{mmol} \mathrm{L}^{-1}\right)$ \\
\hline \multicolumn{4}{|c|}{ Main effects } \\
\hline Standard T & & $12.14 b$ & $0.89 \mathrm{a}$ \\
\hline Low $\mathrm{T}$ & & $14.72 \mathrm{a}$ & $0.46 \mathrm{~b}$ \\
\hline & y" /"Sammy" & 13.36 & 0.64 \\
\hline & to" / "Sammy" & 13.79 & 0.68 \\
\hline & o" / "Sammy" & 13.19 & 0.79 \\
\hline & ery" / "Orangery" & 13.37 & 0.58 \\
\hline & to" / "Orangery" & 13.39 & 0.66 \\
\hline & o" / "Orangery" & 13.48 & 0.72 \\
\hline \multicolumn{4}{|c|}{ Statistical significance } \\
\hline Temperature & & $* * *$ & $* * *$ \\
\hline Grafting combination & & ns & ns \\
\hline Temperature $\times$ graftin & & ns & ns \\
\hline
\end{tabular}

ns and ${ }^{* * *}$ denote "not significant" or significance at $p \leq 0.001$. Means $(n=3)$ followed by different letters within the same column indicate significant differences for each factor according to the Duncan's multiple range test.

Table 5. Mean uptake concentrations (UC) of iron (Fe), manganese (Mn), zinc ( $\mathrm{Zn}$ ), and boron (B) in a pepper crop grown in recirculating nutrient solution during 790 degree-days from treatment initiation, as influenced by temperature $(\mathrm{T})$ and grafting of two cultivated varieties, i.e., "Orangery" and "Sammy", either on their roots or onto the rootstocks "Robusto" and "Terrano".

\begin{tabular}{|c|c|c|c|c|}
\hline $\begin{array}{c}\text { Grafting } \\
\text { Combination } \\
\text { (Rootstock/Scion) }\end{array}$ & Fe UC $\left(\mu \mathrm{mol} \mathrm{L}{ }^{-1}\right)$ & Mn UC $\left(\mu \mathrm{mol} \mathrm{L}^{-1}\right)$ & $\mathrm{Zn} \mathrm{UC}\left(\mu \mathrm{mol} \mathrm{L}{ }^{-1}\right)$ & B UC $\left(\mu \mathrm{mol} \mathrm{L}{ }^{-1}\right)$ \\
\hline \multicolumn{5}{|c|}{ Main effects } \\
\hline Standard T & $18.46 \mathrm{a}$ & $11.08 \mathrm{~b}$ & $7.37 \mathrm{a}$ & 28.97 \\
\hline Low T & $17.16 \mathrm{~b}$ & $12.06 \mathrm{a}$ & $6.61 \mathrm{~b}$ & 29.54 \\
\hline "Sammy" /"Sammy" & 17.80 & $11.35 \mathrm{c}$ & 6.99 & 29.76 \\
\hline "Robusto" /"Sammy" & 18.09 & $11.31 \mathrm{c}$ & 7.18 & 30.36 \\
\hline “Terrano" / "Sammy” & 16.93 & $11.30 \mathrm{c}$ & 6.50 & 28.39 \\
\hline “Orangery" /"Orangery" & 19.04 & $12.23 \mathrm{a}$ & 7.69 & 29.47 \\
\hline “Robusto" / “Orangery" & 18.34 & $11.85 \mathrm{~b}$ & 7.25 & 29.65 \\
\hline “Terrano" / "Orangery” & 16.66 & $11.67 \mathrm{~b}$ & 6.34 & 28.79 \\
\hline \multicolumn{5}{|c|}{ Statistical significance } \\
\hline Temperature & $*$ & $* * *$ & $*$ & ns \\
\hline Grafting combination & ns & $* * *$ & ns & ns \\
\hline Temperature $\times$ grafting & ns & ns & ns & ns \\
\hline
\end{tabular}

$\mathrm{ns}^{*}$, and ${ }^{* * *}$ denote "not significant" or significance at $p \leq 0.05$ and 0.001 . Means $(n=3)$ followed by different letters within the same column indicate significant differences for each factor according to the Duncan's multiple range test.

\section{Discussion}

Pepper is a warm-season crop with a high susceptibility to suboptimal temperatures [33] and, hence, the yield decreases imposed by low temperature in the present study were fully anticipated. However, in the present study, the suppressive effect of low temperatures on pepper yield did not interact with grafting and the rootstock, which indicates that the tested rootstocks have no impact on 
the cold tolerance of pepper. Shu [34] grafted two pepper cultivars onto five different non-commercial rootstocks and found that only one out of the 10 tested grafting combinations had a higher resistance to low temperature. This finding indicates that the tolerance to low temperature in pepper depends not only on the rootstock genotype, however also on the genotype of the scion.

The results of the present study showed that grafting can provide significant benefits to pepper crops in terms of total fruit yield, in agreement with findings of previous investigators [27,35,36]. However, the impact of grafting on fruit yield is depending on the rootstock/scion combination, as also suggested by Rouphael [23], Guimarães [37], and Savvas [38]. Indeed, in the current study, both "Robusto" and "Terrano" increased the total fruit yield by 39\% and 34\% compared with the self-grafted control when the scion was the commercial variety "Sammy". However, when the scion was "Orangery", only "Terrano" was capable of increasing the total fruit yield by $35 \%$ compared with that obtained from self-grafted "Orangery" plants, while "Robusto" had no impact on yield. The yield increases achieved by grafting pepper plants in the present study are appreciably higher than that reported by Jang [39], which amounted to only $9.2 \%$. In agreement with the results of the present study, López-Marín [36] found that grafting of pepper cv. "Herminio" increased yield only when the rootstock was "Creonte", while grafting of "Herminio" onto "Atlante" and "Terrano" had no impact on yield. These findings show that research on the agronomic impact of grafting in pepper crops should be based on testing each individual rootstock/scion combination rather than on screening different rootstocks using just one scion. López-Marín [36] also found that grafting the sweet pepper cultivar Herminio onto the commercial rootstock Creonte had no significant impact on leaf biomass, however it increased the total and marketable fruit yield by $30 \%$ and $50 \%$ under non-shaded and shaded conditions compared to the non-grafted plants, respectively.

In "Sammy", the absence of any impact of grafting on fresh leaf biomass and water consumption despite the significant increase in the fruit number per plant points to a positive effect of both tested rootstocks on fruit setting rather than on plant vigor. A similar response was observed also by López-Marín [36], with the sweet pepper cultivar Herminio grafted onto the commercial rootstock Creonte. On the other hand, when "Orangery" was grafted onto "Terrano" in the present study, both the plant biomass and the water consumption increased proportionally to the increase in fruit number per plant, which indicates that this grafting combination increases yield due to stimulation of plant vigor. Nevertheless, all grafting combinations increased yield exclusively by raising the number of fruit per plant in the present study, while they had no effect on the mean fruit weight. This was surprising as in a previous study, grafting of pepper was found to affect the fruit shape [40], which means that grafting may have an impact on morphological characteristics of each individual fruit. Nevertheless, Colla [35], who grafted the sweet pepper cultivar Edo onto five different rootstocks, found that four of them significantly increased the total fruit yield and in all cases the yield increase was exclusively due to a higher fruit number per plant.

By definition, the impact of grafting on water use efficiency (WUE) depends on both fruit yield and water consumption. Thus, sometimes rootstock/scion combinations imposing quite different effects on yield than on water consumption may result in similar effects on WUE. Indeed, grafting "Orangery" onto "Robusto" had no impact on WUE because it had no impact on both fruit yield and water consumption. However, grafting "Orangery" onto "Terrano" had no impact on WUE because this rootstock/scion combination proportionally increased both the fruit yield and the water consumption as it enhanced the fresh leaf biomass production. Furthermore, grafting "Sammy" increased the WUE irrespective of the tested rootstock because both "Robusto" and "Terrano" increased yield without affecting the vegetative plant biomass and concomitantly the water consumption via transpiration. Colla [35] and López-Marín [36] also found that grafting different scions onto the same rootstock and vice versa may result in different yield responses. These results indicate that the impact of grafting on water use efficiency (WUE) depends on the rootstock/scion combination rather than merely on the rootstock or on the scion. 
Different rootstock/scion combinations may result in increased yield due to a more favorable modulation of several, metabolic, physiological functions, and transcriptomic responses [41,42]. These include favorable changes in hormonal balance between root and shoot [26,43-46], improved resistance to recurrent abiotic and biotic stress [23,46,47], and enhanced nutrient and water uptake due to a more vigorous root system $[26,48]$. In the present investigation, the hormonal balance was not studied, while the single abiotic stress tested, i.e. low temperature, was not alleviated by any grafting combination. However, the measurements of fresh leaf biomass, water consumption, and nutrient uptake allows for an assessment of the contribution of nutrient and water uptake to the observed yield enhancement. Thus, the stimulatory effect of grafting on fruit yield under ST conditions in the present study might be partly associated with enhanced $\mathrm{K}$ and Mg uptake (for "Terrano") or Mg uptake (for "Robusto"). On the other hand, the enhancement of yield by some grafting combinations were observed under both temperature regimes tested in the current study, while the increases in K and $\mathrm{Mg}$ uptake concentrations were observed only in plants cultivated under standard temperature conditions. Furthermore, the uptake concentrations of $\mathrm{Ca}, \mathrm{N}, \mathrm{P}$, and micronutrients were not enhanced by any grafting combination. Thus, a favorable modulation of nutrient uptake efficiency cannot be considered the main reason for the yield increases imposed by some grafting combinations in the present study. Further research is needed to unravel the physiological and molecular mechanisms implicated in the enhancement of total fruit yield by some rootstock/scion combinations.

As reported by Rouphael [23] and Savvas [38], certain grafting combinations may restrict the uptake of some micronutrients and non-nutrient ions, an effect that may be helpful to crops exposed to excessive concentrations of these ions in the root zone. In the present study, both "Robusto" and "Terrano" reduced slightly, however significantly, the Mn uptake by "Orangery", while the same rootstocks, had no impact on Mn uptake when the scion was "Sammy". In a previous study, Ropokis [30] also found no impact of grafting on Mn uptake concentrations. The different responses of "Sammy" and "Orangery" to grafting concerning the Mn uptake further support the notion that the impact of grafting on nutrient uptake depends on the specific rootstock/scion combination rather than on the rootstock genotype.

The increases in the uptake concentrations of $\mathrm{K}, \mathrm{Ca}, \mathrm{Mg}$, and $\mathrm{N}$ under low temperature conditions was a consequence of the reduction in water consumption by $24 \%$. Especially the increases in the uptake concentrations of $\mathrm{Ca}(22 \%)$ and $\mathrm{Mg}(27 \%)$ were very similar to the reduction in water consumption, which indicates that the absolute amounts of $\mathrm{Ca}$ and $\mathrm{Mg}$ absorbed by the crop were not restricted by low temperature, despite the reduction in plant biomass. Unlike the uptake concentrations of metallic micronutrient cations, that of $\mathrm{P}$ was reduced by low temperature. These results indicate that the uptake mechanism of $\mathrm{H}_{2} \mathrm{PO}_{4}{ }^{-}$by pepper is much more susceptible to low temperature than that of $\mathrm{K}, \mathrm{Ca}, \mathrm{Mg}^{2+}$, and N. As shown by Adams [49], the uptake of P responds much stronger to the root temperature than the uptake of $\mathrm{N}$ and $\mathrm{K}$. The low temperature treatments in the present study resulted in low temperatures also in the root zone, which recovered slower during the day than the air temperature. Phosphorus occurs at much lower concentrations in the soil solution compared to other macronutrients [50]. Therefore, during their evolution, plants developed an active uptake mechanism for P uptake, which is much more dependent on the availability of metabolic energy in the roots than for uptake of other nutrients [51]. However, the low root temperature decreases root respiration and, consequently, the availability of metabolic energy for active P uptake [52]. Thus, the profound reduction of $\mathrm{P}$ uptake by pepper in the LT regime may be ascribed mainly to the low root temperature. From another point of view, the results of the present study provide support to the notion that the uptake of $\mathrm{P}$ by pepper is stronger influenced by root temperature than by that prevailing in the air.

The UCs found by Voogt [53] in a pepper crop grown in a closed rockwool system in the Netherlands, averaged for the whole cropping period, were $2.2 \mathrm{mmol} \mathrm{L}^{-1}$ for $\mathrm{Ca}, 0.78 \mathrm{mmol} \mathrm{L}^{-1}$ for $\mathrm{Mg}$, $4.6 \mathrm{mmol} \mathrm{L}^{-1}$ for $\mathrm{K}, 10.30 \mathrm{mmol} \mathrm{L}^{-1}$ for $\mathrm{N}$, and $0.81 \mathrm{mmol} \mathrm{L}^{-1}$ for P. The UC of macronutrients estimated by Ropokis [30] ranged from 2.4 to $3.7 \mathrm{mmol} \mathrm{L}^{-1}$ for Ca, 1.0 to $1.5 \mathrm{mmol} \mathrm{L}^{-1}$ for $\mathrm{Mg}$, 6.2 to $9.0 \mathrm{mmol} \mathrm{L}^{-1}$ for $\mathrm{K}, 11.7$ to $13.7 \mathrm{mmol} \mathrm{L}^{-1}$ for $\mathrm{N}$, and 0.7 to $1.1 \mathrm{mmol} \mathrm{L}^{-1}$ for P. Finally, the average 
UCs found in the present study during the vegetative cropping period under ST conditions were $2.92 \mathrm{mmol} \mathrm{L}^{-1}$ for $\mathrm{Ca}, 0.92 \mathrm{mmol} \mathrm{L}^{-1}$ for $\mathrm{Mg}, 6.03 \mathrm{mmol} \mathrm{L}^{-1}$ for $\mathrm{K}, 12.14 \mathrm{mmol} \mathrm{L}^{-1}$ for $\mathrm{N}$, and 0.89 $\mathrm{mmol} \mathrm{L}^{-1}$ for P. Comparing the data from these three different crops shows that the UC of $\mathrm{Ca}, \mathrm{Mg}, \mathrm{K}$, and $\mathrm{N}$ are generally higher in winter crops of pepper grown under Mediterranean climatic conditions than those reported for Dutch greenhouses, while that of $\mathrm{P}$ is similar in both environments. The values found in the present study are comparable with those found by Ropokis [30] in a previous study, although $\mathrm{Mg}$ and $\mathrm{K}$ tended to be somewhat lower in the current study. Both the present study and that of Ropokis [30] showed that the temperature inside the greenhouse, the cultivar, and the rootstock when using grafted plants may have a significant impact on the UCs. Since these factors may vary in different crops, the UCs found in the three studies are only indicative. Therefore, their use as a basis to prepare nutrient solutions for closed hydroponic systems entails frequent readjustment following measurements of the nutrient concentrations in the root zone of the crop, as suggested by Savvas [31].

\section{Conclusions}

Minimizing greenhouse heating under Mediterranean climatic conditions so as to maintain the minimum inside day $/$ night temperature at $12 / 7^{\circ} \mathrm{C}$, respectively, suppressed the fruit yield of pepper to levels depending on the cultivar, however not on grafting onto "Robusto" or "Terrano". The yield decrease imposed by low temperature (LT) resulted from a reduction of the mean fruit weight (MFW) in "Sammy" and from a reduction of both fruit number per plant (FNP) and MFW in "Orangery".

Grafting of "Sammy" onto both "Robusto" and "Terrano" increased the fruit yield, while grafting of "Orangery" increased yield only when the rootstock was "Terrano". The yield increase imposed by grafting resulted exclusively from enhancement of the fruit number per plant (FNP).

The water use efficiency (WUE) decreased considerably at LT, irrespective of the rootstock. Grafting of "Sammy" significantly increased the WUE irrespective of the scion at LT, however only when the rootstock was "Robusto" at ST. Grafting of "Orangery" had no impact on WUE, irrespective of the rootstock and the temperature regime.

The LT increased the uptake concentrations (UC) of $\mathrm{K}, \mathrm{Ca}, \mathrm{Mg}, \mathrm{N}$, and $\mathrm{Mn}$, while it strongly decreased that of $\mathrm{P}$ and slightly those of $\mathrm{Fe}$ and $\mathrm{Zn}$. The UC of $\mathrm{K}$ and $\mathrm{Mg}$ were influenced by the rootstock/scion combination, however this effect interacted with the temperature regime. In contrast, the $\mathrm{Ca}, \mathrm{N}$, and $\mathrm{P}$ concentrations were not influenced by the grafting combination.

The results of the present study show that the impact of grafting on yield and nutrient uptake in pepper depend not merely on the rootstock genotype, however on the rootstock/scion combination.

Author Contributions: Conceived and designed the experiments: D.S., N.K., G.N., and C.K. Performed the experiments: A.R. and G.N. Analyzed the data: A.R., G.N., N.K., and D.S. Wrote the paper: D.S., A.R., G.N., and N.K. Reviewed the paper: C.K., N.K., and D.S. All authors have read and approved the manuscript.

Acknowledgments: We would like to thank AGROSYSTEM SA for providing us with the grafted plants used in the experiments.

Conflicts of Interest: The authors declare no conflict of interest.

\section{References}

1. Sonneveld, C.; Voogt, W. Plant Nutrition of Greenhouse Crops; Springer: Dordrecht, The Netherlands, 2009; pp. 1-431.

2. Van Noordwijk, M. Synchronisation of supply and demand is necessary to increase efficiency of nutrient use in soilless horticulture. In Plant Nutrition - Physiology and Applications. Developments in Plant and Soil Sciences, 11th ed.; van Beusichem, M.L., Ed.; Springer: Dordrecht, The Netherlands, 1990; pp. 525-531.

3. Adams, P. Nutritional control in hydroponics. In Hydroponic Production of Vegetables and Ornamentals; Savvas, D., Passam, H.C., Eds.; Embryo Publications: Athens, Greece, 2002; pp. 211-261.

4. Sonneveld, C. Composition of nutrient solutions. In Hydroponic Production of Vegetables and Ornamentals; Savvas, D., Passam, H., Eds.; Embryo Publications: Athens, Greece, 2002; pp. 179-210.

5. Carmassi, G.; Incrocci, L.; Maggini, R.; Malorgio, F.; Tognoni, F.; Pardossi, A. Modelling salinity buildup in recirculating nutrient solution culture. J. Plant Nutr. 2005, 28, 431-445. [CrossRef] 
6. Gallardo, M.; Thompson, R.B.; Rodríguez, J.S.; Rodríguez, F.; Fernández, M.D.; Sánchez, J.A.; Magán, J.J. Simulation of transpiration, drainage, $\mathrm{N}$ uptake, nitrate leaching, and $\mathrm{N}$ uptake concentration in tomato grown in open substrate. Agric. Wat. Manag. 2009, 96, 1773-1784. [CrossRef]

7. Neocleous, D.; Savvas, D. Effect of different macronutrient cation ratios on macronutrient and water uptake by melon (Cucumis melo) grown in recirculating nutrient solution. J. Plant Nutr. Soil Sci. 2015, 178, 320-332. [CrossRef]

8. Sonneveld, C.; Voogt, W. Response of tomatoes (Lycopersicon esculentum) to an unequal distribution of nutrients in the root environment. Plant Soil. 1990, 124, 251-256. [CrossRef]

9. Hopmans, J.W.; Bristow, K.L. Current capabilities and future needs of root water and nutrient uptake modeling. Adv. Agr. 2002, 77, 104-175.

10. Seginer, I. A dynamic model for nitrogen-stressed lettuce. Ann. Bot. 2003, 91, 623-635. [CrossRef] [PubMed]

11. Adams, P.; Ho, L.C. Effects of environment on the uptake and distribution of calcium in tomato and the incidence of blossom-end rot. Plant Soil. 1993, 154, 127-132. [CrossRef]

12. Savvas, D.; Lenz, F. Naehrstoffaufnahme von Aubergine (Solanum melongena L.) in Hydrokultur. Gartenbauwissenschaft 1995, 60, 29-33.

13. Kläring, H.P.; Schwarz, D.; Heissner, A. Control of nutrient solution concentration in tomato using models of photosynthesis and transpiration: A simulation study. Acta Hortic. 1997, 450, 329-334. [CrossRef]

14. Hansen, J.D.; Hara, A.H. A review of postharvest disinfestation of cut flowers and foliage with special reference to tropicals. Postharv. Biol. Technol. 1994, 4, 193-212. [CrossRef]

15. Criddle, R.S.; Smith, B.N.; Hansen, L.D. A respiration based description of plant growth rate responses to temperature. Planta 1997, 201, 441-445. [CrossRef]

16. Amalfitano, C.; Del Vacchio, L.; Somma, S.; Cuciniello, A.; Caruso, G. Effects of cultural cycle and nutrient solution electrical conductivity on plant growth, yield and fruit quality of "Friariello" pepper grown in hydroponics. Hortic. Sci. 2017, 44, 91-98.

17. Mercado, J.A.; Trigo, M.M.; Reid, M.S.; Valpuesta, V.; Quesada, M.A. Effects of low temperature on pepper pollen morphology and fertility: Evidence of cold induced exine alterations. J. Hortic. Sci. 1997, 72, 317-326. [CrossRef]

18. Elfving, D.C.; Kaufmann, M.R.; Hall, A.E. Interpreting leaf water potential measurements with a model of the soil-plant-atmosphere continuum. Physiol. Plant. 1972, 27, 161-168. [CrossRef]

19. Fennell, A.; Markhart, H.A. Rapid acclimation of root hydraulic conductivity to low temperature. J. Exp. Bot. 1998, 49, 879-884. [CrossRef]

20. Bie, Z.; Nawaz, M.A.; Huang, Y.; Lee, J.M.; Colla, G. Introduction to vegetable grafting. In Vegetable Grafting: Principles and Practices; Colla, G., Pérez-Alfocea, F., Schwarz, D., Eds.; CABI: Oxfordshire, UK, 2017; pp. 1-21.

21. Rivard, C.L.; Louws, F.J. Grafting to manage soilborne diseases in heirloom tomato production. HortSci. 2008, 43, 2104-2111. [CrossRef]

22. Schwarz, D.; Rouphael, Y.; Colla, G.; Venema, J.H. Grafting as a tool to improve tolerance of vegetables to abiotic stresses: Thermal stress, water stress and organic pollutants. Sci. Hortic. 2010, 127, 162-171. [CrossRef]

23. Rouphael, Y.; Venema, J.H.; Edelstein, M.; Savvas, D.; Colla, G.; Ntatsi, G.; Ben-Hur, M.; Kumar, P.; Schwarz, D. Grafting as a Tool for Tolerance of Abiotic Stress. In Vegetable Grafting: Principles and Practices; Colla, G., Pérez-Alfocea, F., Schwarz, D., Eds.; CABI: Oxfordshire, UK, 2017; pp. 171-215.

24. Flores, F.B.; Sanchez-Bel, P.; Estan, M.T.; Martinez-Rodriguez, M.M.; Moyano, E.; Morales, B.; Campos, J.F.; Garcia-Abellán, J.O.; Egea, M.I.; Fernández-Garcia, N.; et al. The effectiveness of grafting to improve tomato fruit quality. Sci. Hortic. 2010, 125, 211-217. [CrossRef]

25. Colla, G.; Rouphael, Y.; Leopardi, C.; Bie, Z. Role of grafting in vegetable crops grown under saline conditions. Sci. Hortic. 2010, 127, 147-155. [CrossRef]

26. Lee, J.M.; Kubota, C.; Tsao, S.J.; Bie, Z.; Hoyos Echevarria, P.; Morra, L.; Oda, M. Current status of vegetable grafting: Diffusion, grafting techniques, automation. Sci. Hortic. 2010, 127, 93-105. [CrossRef]

27. Penella, C.; Landi, M.; Guidi, L.; Nebauer, S.G.; Pellegri, E.; San Bautista, A.; Remorini, D.; Nali, C.; López-Galarza, S.; Calatayud, A. Salt-tolerant rootstock increases yield of pepper under salinity through maintenance of photosynthetic performance and sinks strength. J. Plant Phys. 2016, 193, 1-11. [CrossRef] [PubMed] 
28. Sánchez-Solana, F.; Ros, C.; Guerrero, M.; Lacasa, C.; Sánchez-López, E.; Lacasa, A. New pepper accessions proved to be suitable as a genetic resource for use in breeding nematode-resistant rootstocks. Plant Gen. Resour. 2016, 14, 28-34. [CrossRef]

29. López-Marín, J.; Gálvez, A.; del Amor, F.M.; Albacete, A.; Fernández, J.A.; Egea-Gilabert, C.; Pérez-Alfocea, F. Selecting vegetative/generative/dwarfing rootstocks for improving fruit yield and quality in water stressed sweet peppers. Sci. Hortic. 2017, 214, 9-17. [CrossRef]

30. Ropokis, A.; Ntatsi, G.; Kittas, C.; Katsoulas, N.; Savvas, D. Impact of cultivar and grafting on nutrient and water uptake by sweet pepper (Capsicum annuum L.) grown hydroponically under Mediterranean climatic conditions. Front Plant Sci. 2018, 9, 1244. [CrossRef] [PubMed]

31. Savvas, D.; Gruda, N. Application of soilless culture technologies in the modern greenhouse industry-A review. Eur. J. Hortic. Sci. 2018, 83, 280-293. [CrossRef]

32. Tzerakis, C.; Savvas, D.; Sigrimis, N.; Mavrogiannopoulos, G. Uptake of Mn and Zn by cucumber grown in closed hydroponic systems as influenced by the $\mathrm{Mn}$ and $\mathrm{Zn}$ concentrations in the supplied nutrient solution. HortSci. 2013, 48, 73-379. [CrossRef]

33. Airaki, M.; Leterrier, M.; Mateos, R.M.; Valderrama, R.; Chaki, M.; Barroso, J.B.; Corpas, F.J. Metabolism of reactive oxygen species and reactive nitrogen species in pepper (Capsicum annuum L.) plants under low temperature stress. Plant Cell Envir. 2012, 35, 281-295. [CrossRef] [PubMed]

34. Shu, C.; Yang, R.; Yin, L.; Ai, X.; Wang, S.; Zhao, W. Selection of rootstocks for better morphological characters and resistance to low-temperature stress in the sweet pepper cultivar 'Hongxing No. 2'. Hortic. Environ. Biotechnol. 2016, 57, 348-354. [CrossRef]

35. Colla, G.; Rouphael, Y.; Cardarelli, M.; Temperini, O.; Rea, E.; Salerno, A.; Pierandrei, F. Influence of grafting on yield and fruit quality of pepper (Capsicum annuum L.) grown under greenhouse conditions. Acta Hortic. 2008, 782, 359-363. [CrossRef]

36. López-Marín, J.; González, A.; Pérez-Alfocea, F.; Egea-Gilabert, C.; Fernández, J.A. Grafting is an efficient alternative to shading screens to alleviate thermal stress in greenhouse-grown sweet pepper. Sci. Hortic. 2013, 149, 39-46. [CrossRef]

37. Guimarães, M.D.A.; Gustin, J.L.; Salt, D.E. Reciprocal grafting separates the roles of the root and shoot in zinc hyperaccumulation in Thlaspi caerulescens. New Phytol. 2009, 184, 323-329. [CrossRef] [PubMed]

38. Savvas, D.; Colla, G.; Rouphael, Y.; Schwarz, D. Amelioration of heavy metal and nutrient stress in fruit vegetables by grafting. Sci. Hortic. 2010, 127, 156-161. [CrossRef]

39. Jang, Y.; Yang, E.; Cho, M.; Um, Y.; Ko, K.; Chun, C. Effect of grafting on growth and incidence of phytophthora blight and bacterial wilt of pepper (Capsicum annuum L.). Hortic. Environ. Biotechnol. 2012, 53, 9-19. [CrossRef]

40. Tsaballa, A.; Athanasiadis, Ch.; Pasentsis, K.; Ganopoulos, I.; Nianiou-Obeidat, I.; Tsaftaris, A. Molecular studies of inheritable grafting induced changes in pepper (Capsicum annuum) fruit shape. Sci. Hortic. 2013, 149, 2-8. [CrossRef]

41. Ntatsi, G.; Savvas, D.; Druege, U.; Schwarz, D. Contribution of phytohormones in alleviating the impact of sub-optimal temperature stress on grafted tomato. Sci. Hortic. 2013, 149, 28-38. [CrossRef]

42. Ntatsi, G.; Savvas, D.; Papasotiropoulos, V.; Katsileros, A.; Zrenner, R.M.; Hincha, D.K.; Zuther, E.; Schwarz, D. Rootstock sub-optimal temperature tolerance determines transcriptomic responses after long-term root cooling in rootstocks and scions of grafted tomato plants. Front Plant Sci. 2017, 8, 911. [CrossRef] [PubMed]

43. Albacete, A.; Martínez-Andújar, C.; Ghanem, M.E.; Acosta, M.; Sánchez-Bravo, J.; Asins, M.J.; Cuartero, J.; Lutts, S.; Dodd, I.C.; Pérez-Alfocea, F. Rootstock-mediated changes in xylem ionic and hormonal status are correlated with delayed leaf senescence, and increased leaf area and crop productivity in salinized tomato. Plant. Cell Envir. 2009, 32, 928-938. [CrossRef] [PubMed]

44. Venema, J.H.; Giuffrida, F.; Paponov, I.; Albacete, A.; Pérez-Alfocea, F.; Dodd, I.C. Rootstock-scion signalling: Key factors mediating scion performance. In Vegetable Grafting: Principles and Practices; Colla, G., Pérez-Alfocea, F., Schwarz, D., Eds.; CABI: Oxfordshire, UK, 2017; pp. 94-131.

45. Ntatsi, G.; Savvas, D.; Huntenburg, K.; Druege, U.; Hincha, D.K.; Zuther, E.; Schwarz, D. A study on ABA involvement in the response of tomato to suboptimal root temperature using reciprocal grafts with notabilis, a null mutant in the ABA-biosynthesis gene LeNCED1. Environ Exp Bot. 2014, 97, 11-21. [CrossRef] 
46. Ntatsi, G.; Savvas, D.; Kläring, H.-P.; Schwarz, D. Growth, yield, and metabolic responses of temperature-stressed tomato to grafting onto rootstocks differing in cold tolerance. J. Am. Soc. Hortic. Sci. 2014, 139, 230-243. [CrossRef]

47. Cohen, R.; Dombrovsky, A.; Louws, F.J. Grafting as agrotechnology for reducing disease damage. In Vegetable Grafting: Principles and Practices; Colla, G., Pérez-Alfocea, F., Schwarz, D., Eds.; CABI: Oxfordshire, UK, 2017; pp. 155-171.

48. King, S.R.; Davis, A.R.; Zhang, X.; Crosby, K. Genetics, breeding and selection of rootstocks for Solanaceae and Cucurbitaceae. Sci. Hortic. 2010, 127, 106-111. [CrossRef]

49. Adams, P. Nutrition of greenhouse vegetables in $\mathrm{nft}$ and hydroponic systems. Acta Hortic. 1994, 361, $245-257$. [CrossRef]

50. Bieleski, R.L. Phosphate pools, phosphate transport, and phosphate availability. Annu. Rev. Plant Physiol. 1973, 24, 225-252. [CrossRef]

51. Schachtman, D.P.; Reid, R.J.; Ayling, S.M. Phosphorus uptake by plants: From soil to cell. Plant Physiol. 1998, 116, 447-453. [CrossRef] [PubMed]

52. Sutton, C.D. Effect of low soil temperature on phosphate nutrition of plants - A review. J. Sci. Food Agric. 1969, 20, 1-3. [CrossRef]

53. Voogt, W.; Sonneveld, C. Nutrient Management in Closed Growing Systems for Greenhouse Production. In Plant Production in Closed Ecosystems; Goto, E., Kurata, K., Hayashi, M., Sase, S., Eds.; Springer: Dordrecht, The Netherlands, 1997; pp. 83-102.

(C) 2019 by the authors. Licensee MDPI, Basel, Switzerland. This article is an open access article distributed under the terms and conditions of the Creative Commons Attribution (CC BY) license (http://creativecommons.org/licenses/by/4.0/). 